\title{
UTLÄNNINGAR I SVENSKA FÄNGELSER
}

Av GENERALDIREKTÖR BERTEL ÖSTERDAHL

Discussions regarding the criminality of foreigners tend to be tainted by passion, inaccuracy, and myth. Therefore, it is important to begin with the relevant facts. Approximately $25 \%$ of all sentenced persons in Sweden are foreigners, a heavy over-representation when compared to their presence in the broader Swedish society. Among prisoners, first-generation foreigners are over-represented by a factor of 2,1, and their children by a factor of 1,5. Closer analysis shows that this over-representation is even stronger in regard to drug and robbery offenses, but that foreigners are under-represented for offenses concerning traffic and drunkenness. In recent years, the percentage of prisoners from Eastern Europe and the Orient has increased.

Foreigners do not present any special behavioral problems in the Swedish prisons. They are relatively well-disciplined, generally work very hard, and often send their earnings home to their families. Conflicts between foreign and non-foreign inmates tend to be based upon individual disagreements rather than ethnic background.

Foreigners do tend to be more isolated than their non-foreign counterparts, primarily because of their lack of visitors, limited access to television from their home countries, and - in some cases - to an insufficient knowledge of the Swedish language.

To diminish existing problems, the prison system should recruit personnel from a broader spectrum of ethnic backgrounds, and develop special programs for those designated for deportation upon completion of their sentences. The rehabilitation of foreign prisoners would be enhanced by an increase in prisoner exchange agreements that allow foreign prisoners to serve or complete their sentences in their home countries. It is particularly important for the Nordic countries to focus on this issue, despite humanitarian questions concerning the ethics of sending sentenced persons back to countries which demonstrate low humanitarian levels in regard to treatment of offenders.

\section{Inledning}

Utlänningar och brottslighet är ett ämne som med jämna mellanrum dyker upp i massmedia. Ibland kan vissa främlingsfientliga och okunniga grupper utnyttja detta för att skapa myter, fördomar och främlingsfientlighet.

Ett gott skäl för att ta upp detta ämne tycker jag är att försöka bringa reda i

\footnotetext{
* Title in English: Foreigners in the Swedish Prisons. Original in Swedish.
} 
fakta och bekämpa de myter som finns. Därför är jag mycket tacksam för att få detta tillfälle att dels redovisa situationen i Sverige och även komma med en del synpunkter i ett så kvalificerat debattforum som detta.

Den stora frågan är naturligtvis: Begår utlänningar flera brott än den egna befolkningen? Ja, vid ett enkelt betraktande tycks det så, detta av den enkla anledningen att de är överrepresenterade i fängelserna, åtminstone i de flesta länder jag har haft möjlighet att studera.

En intressant fråga är: Beror detta verkligen på att de begår flera brott eller kan det vara så enkelt att de lättare åker fast av någon anledning?

Jag har inget svar men jag tycker inte att man kan gå förbi frågeställningen utan att åtminstone ägna den en tanke.

I en svensk undersökning gjord av Jan Ahlberg på Brottsförebyggande Rådet (BRÅ) pekar han emellertid på att vuxna invandrare är överrepresenterade med faktorn 2,1 och deras barn med faktorn 1,5. Han menar i sin studie att det beror bl a på att en högre andel kriminella hör till invandrargrupperna samt att invandrarsituationen i sig kan generera en viss brottslighet. Han hävdar att upptäcktsrisken i sig inte är större för utlänningar.

En teori som jag själv dristar mig framföra och som jag inte har något vetenskapligt belägg för är att främlingskap och utanförstående kan ha ett visst samband med hög brottslighet. Några exempel: Maorierna på Nya Zeeland är dramatiskt överrepresenterade i sitt lands fängelser, likaså indianerna i Canada. Ett annat exempel är zigenarna i Ungern. Enligt vad som sades mig under ett besök där utgör de $50 \%$ av fängelsepopulationen men endast $6 \%$ av befolkningen.

Det finns exempel även på motsatsen. Samerna i Sverige är såvitt jag vet mycket sällan förekommande i våra fängelser.

Som jag ser det är det mycket viktigt att ge dessa problem deras rätta dimensioner och undvika mytbildning. Jag skall därför inleda med att redovisa några fakta från Sverige.

Jag börjar med andelen utlänningar som under 90-talet har växlat mellan 20 och $25 \%$ (figur 1). Jag bedömer att den svagt ökande andelen beror på att antalet utländska medborgare i samhället ökat.

Figur 1. Andel (\%) utländska medborgare som intagits i anstalt 1991-1999

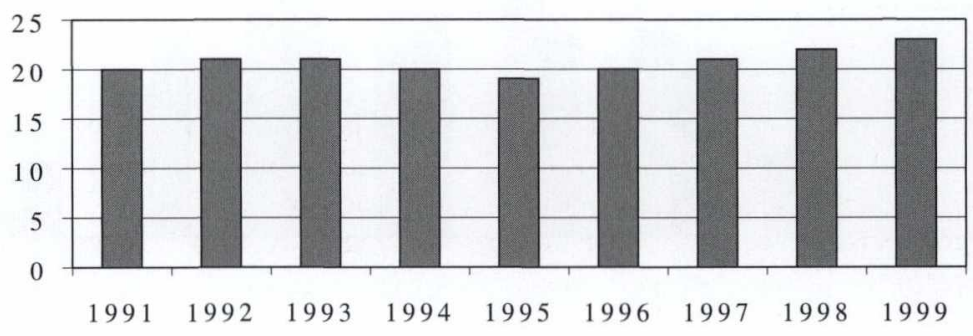


I Sverige innebär vissa typer av brott att de intagna utvisas efter avtjänat straff. Antalet har under hela 90-talet legat relativt konstant. Ar 1999 passerade 2300 utländska medborgare svenska fängelser. Av dessa utvisades 366, dvs 16\% (figur 2).

Figur 2. Antal utländska medborgare 1999 varav antal utvisade

$\square$ Antal utländska medborgare $\mathbf{U}$ tvisning i domen

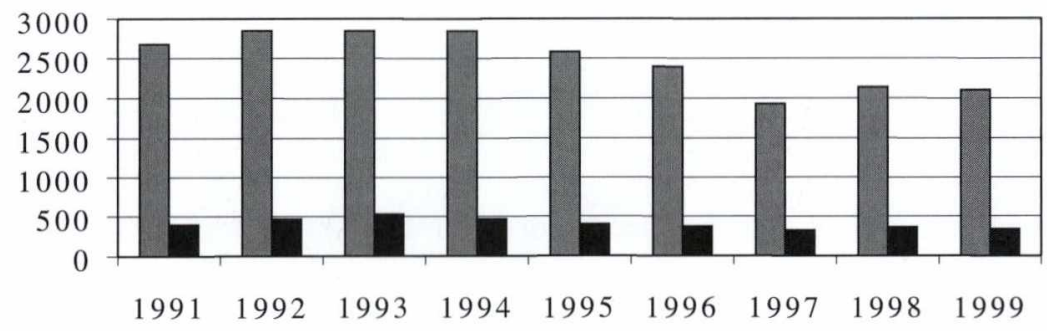

Tittar man på åldrarna finner man att antalet unga brottslingar med utländskt medborgarskap är överrepresenterade, medan de är underrepresenterade när vi kommer upp i fyrtioårsåldern (figur 3).

Figur 3. Andel (\%) intagna 1999 uppdelat på ålder

\section{Totalt $\square$ Utländska medborgare}

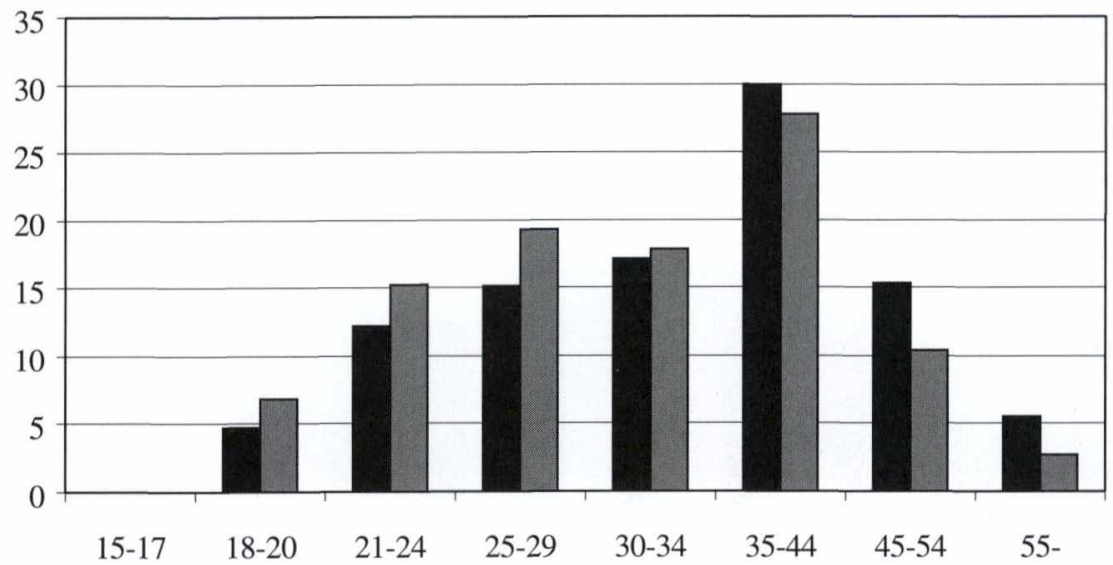


Tittar man på vilka brott som begås så finner vi en påtaglig överrepresentation när det gäller narkotikabrott liksom vid brott mot stat och allmänhet samt rån och sexualbrott. Däremot är utlänningarna underrepresenterade vad gäller trafikbrott och rattfylleri.

Figur 4. Andel (\%) intagna 1999 uppdelat på huvudbrott

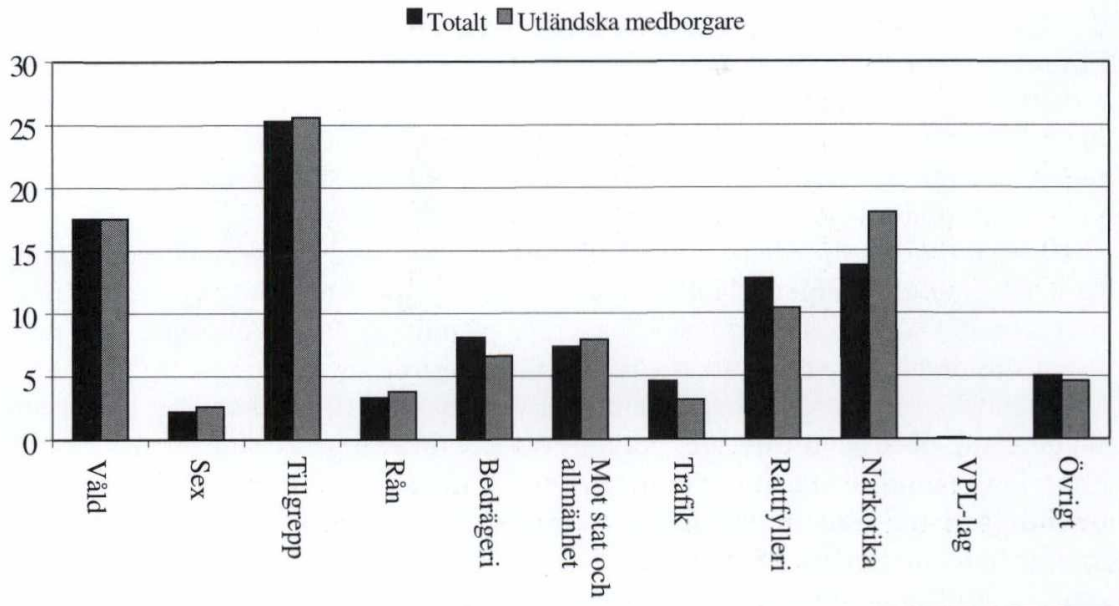

Tittar vi på straffsidan så finner vi att som en logisk följd av att det bland utlänningar är en överrepresentation när det gäller narkotikabrott så är det även en överrepresentation när det gäller straff över två år.

Det kan också vara av intresse att se varifrån brottslingarna kommer. Här finner vi att antalet från Östeuropa och Orienten är relativt stort. Antalet har ökat under de senaste åren (figur 5).

Figur 5. Antal personer som intagits 1999 uppdelat på medborgarskap och världsdelar. Drygt 100 olika medborgarskap. 7199 personer med svenskt medborgarskap redovisas ej här

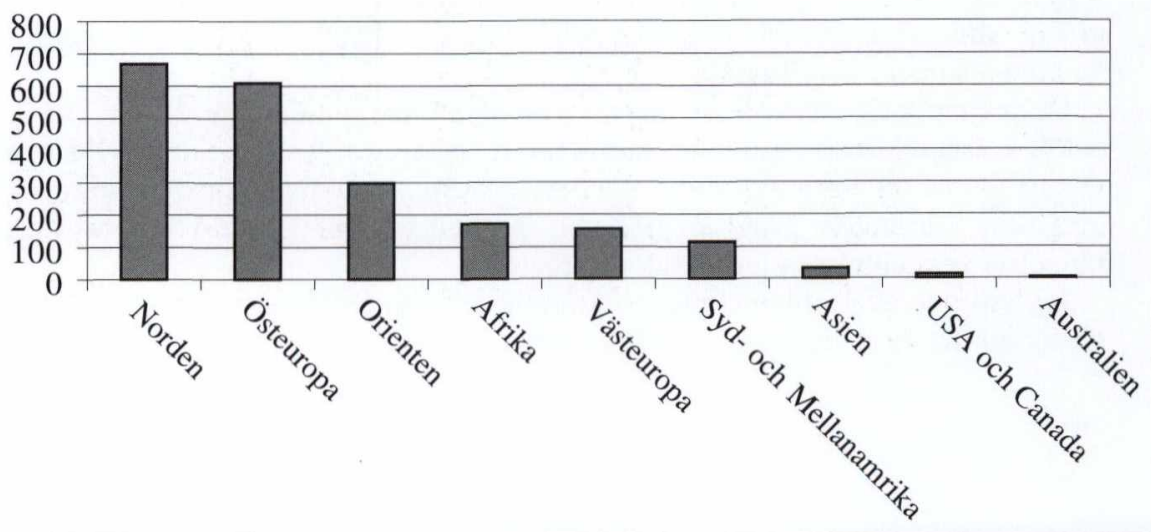


Utländska medborgare är starkt överrepresenterade i fängelser med hög säkerhetsklass. Ibland utgör de t o m över $50 \%$. Det har sin förklaring bl a i att vissa har begått mycket grova narkotikabrott och även en del allvarliga våldsbrott.

Jag avslutar min faktaredovisning med att upplysa om att utländska medborgare i fängelse kostar mellan 250-260 miljoner kr per år i en budget på nästan 4 miljarder kr.

\section{Några problem kring utländska medborgare i fängelse}

För människor som vill utveckla fördomar ligger det nära till hands - i synnerhet vid ett tillfälle som detta - att framställa utlänningar i fängelse som ett stort problem. Med risk att jag något förtar bornyren i den följande diskussionen vill jag redan nu säga att som vi ser det i Sverige är så ej fallet. Detta hindrar naturligtvis inte att utlänningar själva kan uppleva det problematiskt.

I Sverige genomfördes 199627 djupintervjuer med fängelsepersonal som hade att arbeta nära bl a utländska intagna. De synpunkter som jag nedan kommer att redovisa och som främst är baserade på mina egna diskussioner med personal stämmer väl överens med vår undersökning.

Utländska medborgare begår jämförelsevis få allvarliga förseelser under sin fängelsetid, de arbetar ofta bra, betydligt bättre än många av sina svenska kamrater. De är inställda på att tjäna pengar, vilket de i vissa fall faktiskt också gör i betydligt högre grad än vad de har möjlighet till i respektive hemland. Många sänder hem sina intjänade pengar till sina familjer och de strävar efter att genomföra strafftiden under så lugna förhållanden som möjligt.

De nordiska medborgarna håller gärna ihop. På motsvarande sätt finns en sammanhållning mellan andra nationaliteter. Vi har noterat att problem kan uppstå om någon grupp blir för stor till antalet. Vi kan då se tendenser till att de vill ta över makten inom fångkollektivet.

Naturligtvis förekommer det konflikter mellan intagna med utländsk bakgrund. Dessa är emellertid i allt väsentligt personrelaterade och inte kopplade till deras bakgrund i olika kulturer.

Självklart finns det problem, framför allt tror jag att de intagna själva upplever dem som betydligt större än vad vår egen personal gör. De utländska medborgarna är givetvis isolerade i högre grad än de svenska intagna. Vissa får inga som helst besök, en hel del har språksvårigheter även om dessa inte skall överdrivas. Många kan faktiskt engelska och lär sig efter hand tillräckligt mycket för att kunna hantera sin situation.

De saknar dock ofta kontakt med hemlandet i form av tidningar, tv osv. Det är också svårt att hitta programverksamhet som de upplever som meningsfylld, bl a för att gagna en återanpassning till det svenska samhället. För dem som har utvisning i domen är program av detta slag helt verkningslösa och deras tid i fängelset koncentreras i huvudsak på arbete.

Jag vill inte ge problemet med olika religioner en alltför stor dimension, bl a därför att det visat sig att muslimer accepterar kristna präster. 
I Sverige har vi påbörjat ett särskilt hemvändarprogram på en avdelning som vi inrättat enbart för utvisningsdömda på Kumla-anstalten. Det är ännu alldeles för tidigt att utvärdera resultatet. De intagna har emellertid efter viss tveksamhet inledningsvis tagit emot det positivt. För att verksamheten skall bli effektiv krävs bl a kulturkompetens och språkkunskaper som vi inte har tillgång till i önskvärd omfattning.

Permissionsmöjligheterna är naturligtvis avsevärt mindre för dem som har utvisning i domen än för andra och det gör givetvis fängelsevistelsen extra tung bl a med tanke på att strafftiderna som regel är långa.

Ett annat problem skulle kunna vara diskriminering men i en undersökning som en journalist nyligen gjorde över ämnet visade det sig, att de intagna inte känner sig diskriminerade av personalen. Däremot kan det kanske - trots vad jag tidigare sagt - i vissa fall förekomma motsättningar mellan olika grupper som kan upplevas som diskriminerande.

För vissa kan maten vara ett problem. Att alla inte uppskattar svenska köttbullar eller ärtsoppa får vi kanske ha viss förståelse for. För dem som av religiösa eller andra skäl inte äter vissa rätter har vi möjligheter att erbjuda alternativ.

Jag kan också tänka mig att förståelsen för olika minoriteters särskilda kulturer inte är så utvecklad överallt. Vi genomför dock viss utbildning bland personal på fängelser där antalet utlänningar är stort för att råda bot på detta.

\section{Vad kan vi då göra åt de problem som ändå finns?}

För det första bör vi rekrytera personal med annan etnisk bakgrund och med kunskaper i vissa främmande språk utöver engelska. Det är emellertid inte helt lätt, då många i övrigt väl kvalificerade invandrare inte har den önskade språkkunskapen (i svenska) och ej heller önskvärd skolbakgrund.

Vi bör också utveckla våra program för att underlätta för dem med utvisning $\mathrm{i}$ domen att återvända hem till respektive land. Det har vid några tillfällen diskuterats framför allt på politisk nivå att bygga ett särskilt fängelse enbart för utlänningar. Jag anser emellertid att detta är både olämplig och frågan är för närvarande inte aktuell i Sverige.

Däremot har vi på Kumla-anstalten inrättat en särskild avdelning just för intagna med utvisning i domen. Dessa intagna upplever det positivt trots att vi ännu inte har så hög kvalitet på den verksamheten som vi skulle önska.

Vad jag emellertid tycker är viktigt det är att få till stånd internationella överenskommelser som gör att så många som möjligt kan få fullgöra sitt straff $\mathrm{i}$ respektive hemland. Det går utmärkt bra här i Norden där vi har avtal i frågan men är svårt gentemot många andra länder.

Ett problem är härvid att överlämnandekonventionen (FN) säger att det krävs frivillighet för att någon skall sändas tillbaka till sitt hemland. Det fanns goda skäl för detta tidigare, då man t ex i kommunistvärlden kunde utdöma väsentligt hårdare straff, $\mathrm{t} \mathrm{o} \mathrm{m}$ dödsstraff. Sverige driver sedan ett antal år denna fråga. Det 
har varit svårt att få gehör i vissa länder tidigare, men nu synes förståelsen för idén ha ökat, bl a manifesterat i ett tilläggsprotokoll till ovannämnda konvention, som dock endast ett begränsat antal länder undertecknat, bl a Sverige.

Att fullgöra sitt straff i respektive hemland har en klar fördel när det gäller utslussning och bibehållandet av kontakter med familj, eventuella arbetsgivare $\mathrm{m} \mathrm{m}$. Jeg inser naturligtvis det diskutable $\mathrm{i}$ att sända iväg de dömda till hemländer med låg humanitär nivå på sin kriminalvård.

Jag tycker att det internationella samfundet bör driva frågan betydligt mer energiskt än vad som nu är fallet. En intressant problematik är härvid: Om det vore känt att alla länder i princip skulle få tillbaka sina egna brottslingar, skulle detta då ha någon avhållande effekt på vissa brottslingar som besöker andra länder i akt och mening att begå brott? Jag har inget svar på den frågan.

\section{Avslutning}

Sammanfattningsvis kan sägas att utländska medborgare är överrepresenterade i svenska fängelser, men vi anser inte att de utgör något stort problem. De flesta sköter sig jämförelsevis väl. Vi kan dock göra mer för att i synnerhet de med utvisning i domen skall få bättre möjligheter till återanpassning i sitt hemland.

Bästa lösningen, i de flesta fall, är som jag ser det att de dömda får fullgöra sina straff $i$ respektive hemland.

Jag tycker att inte minst vi i de nordiska länderna gemensamt bör driva denna fråga med kraft.

Adress: Kriminalvården

Slottsgatan 78

SE-601 80 Norrköping 